\title{
THREE NEW SPECIES OF THE GENUS CATRIONA FROM JAPAN (NUDIBRANCHIA-EOLIDACEA)
}

AUTHOR(S):

Baba, Kikutaro

\section{CITATION:}

Baba, Kikutaro. THREE NEW SPECIES OF THE GENUS CATRIONA FROM JAPAN (NUDIBRANCHIA-EOLIDACEA). PUBLICATIONS OF THE SETO MARINE BIOLOGICAL LABORATORY 1961, 9(2):367-372

ISSUE DATE:

1961-12-20

URL:

http://hdl.handle.net/2433/175287

RIGHT: 


\title{
THREE NEW SPECIES OF THE GENUS CATRIONA FROM JAPAN (NUDIBRANCHIA-EOLIDACEA) ${ }^{1)}$
}

\author{
KIKUTARÔ BABA \\ Biological Laboratory, Osaka Gakugei University
}

With Plates $X I V-X V$ and 1 Text-figure

The acleioproctic family Cuthonidae consists of the genera: Cuthona, Precuthona, Cuthonella, Phestilla, Catriona (=Cratena in older use), Cratenopsis, Indocratena, Xenocratena, Njurja, ?Diaphoreolis, ? Noumeaella, ?Globiferina, ? Ennoia, ? Myja, ?Dunga, ?Zatteria and ?Guy-valvoria.

Catriona is a large genus (see the synopsis of the species by MARcus, 1958, pp. 49-52). It is especially distinct from the allied genus Cuthona in having a chitinous armature of the penis (penis stylet). The male and female orifices are united. The median cusp of the radula teeth is not so prominent like in Cuthona, and sometimes it is retracted (see the distinction of Catriona from Cuthona given by Odhner, 1939, p. 53; E. \& E. Marcus, 1959, pp. 917-918; see also MACNAE, 1954, pp. 3-4). The species of Catriona previously recorded from our seas are enumerated below ${ }^{2)}$ :

1. Catriona ornata (BABA, 1937)=Cuthona ornata BABA, 1937 Fujiera-minoumiushi

Loc.: Sagami Bay ; Sugashima near Toba ; Osaka Bay ; Inland Sea of Seto;

Sado I. ; Toyama Bay; Togi Kazanashi, W. coast of Noto Peninsula ;

Tsuruga Bay.

Penis armed with stylet.

2. Catriona venusta (BABA, 1949)=Cratena venusta BABA, 1949 Hanazonominoumiushi

Loc. : Sagami Bay.

Penis not determined.

3. Catriona anulata (BABA, 1949) =Cratena anulata BABA, 1949 Tsunowaminoumiushi

Loc.: Sagami Bay.

1) Contributions from the Seto Marine Biological Laboratory, No. 373.

2) Amphorina? sp. Eliot, 1913, is left undetermined. Cratena bicolor (BABA, 1933)=Cuthona bicolor BABA, 1933 (non Cuthona? bicolor BERGH, 1904) is excluded from Catriona (see MĄRCUS, 1958, p. 49); it will be discussed later.

Publ. Seto Mar. Biol. Lab., IX (2), 1961. (Article 19) 
Penis not determined.

4. Catriona pinnifera (BABA, 1949)=Cratena pinnifera BABA, 1949 . Tsunobaneminoumiushi

Loc.: Sagami Bay; Kii ; Osaka Bay; Toyama Bay; Tsuruga Bay.

Penis armed with stylet.

5. Catriona puellula (BABA, 1955) = Cratena puellula $\mathrm{BABA}, 1955$ Kirihimeminoumiushi

Loc.: Sagmi Bay; Toyama Bay.

Penis not determined.

6. Catriona nigricolora $(\mathrm{BABA}, 1955)=$ Cratena nigricolora BABA, 1955 Kurominoumiushi

Loc.: Sagami Bay.

Penis not determined.

Catriona pupillae BABA, n. sp.

Komayu-minoumiushi (n. n.)

(Pl. XIV, Figs. 1, a, b-5; Text-fig. 1, A)

This species is somewhat allied to $C$. susa E. \& E. MARcus, 1959, from the Red Sea, in the arrangement of the gills. Animal always small, 3-5 mm in total length. With cephalic tentacles and rhinophores, the latter slightly longer and smooth. Branchial papillae short, of an inflated fusiform, arranged in 4-6 simple oblique rows on each side, about 3-4 in the largest rows, the foremost 2 rows belonging to the right liver (and the left partner). Genital orifice situated below the 1st rcw on the right side, the anus in front of the 3rd row on the same side, the nephroproct closely preanal. Foot-corners rounded. General bodycolour translucent whitish, covered with opaque white dots on head and back. Cephalic tentacles and rhinophores nearly always marked with an orange-yellow band at about the middle of their length. Branchial papillae with an opaque white cap and a band of the same colour down the tip; liver diverticulum within the papillae, dark brown. A row of 17-20 denticles on the masticatory edge of the jaw-plates. Radula formula $30 \times 0.1 .0$. The median cusp of the tooth is slightly longer than the lateral (4-5) denticles. In C. susa, it is said that each of the teeth has 3 median cusps longer than the lateral denticles. Genitalia as usual in the genus, the penis having an apical stylet.

Loc.: Tannowa, Osaka Bay, shallow water (Mar. 1951 and 1952, 4 sps., coll. by Mr. Hamatani); Kada, Osaka Bay (Mar. 1957, 2 sps., coll. by Mr. Hamatani).

Additional localities of this species are: Mukaishima, Inland Sea of Seto; Nou and Awashima, Niigata Pref.; Toyama Bay; Tsuruga Bay; not rare. The actual specimens in these stations have been obtained by Dr. INABA as well as by Mr. ABE and his co-workers. 


\section{Catriona signifera BABA, n. $\mathrm{sp}$.}

Monsyo-minoumiushi (n. n.)

(P1. XIV, Figs. 6, a, b-9; P1. XV, Figs. 1-2; Text-fig. 1, B)

Very distinctive in having an ovoid marking behind the rhinophores on the back. Total length of animal 5-8 mm. Rhinophores as long as the cephalic ten. tacles, smooth. Branchial papillae long fusiform, arranged in 8-9 simple oblique rows on back margins, about $3-4$ in the largest rows, the foremost 3 rows belonging to the right liver (and the left partner). Genital orifice below the 2nd

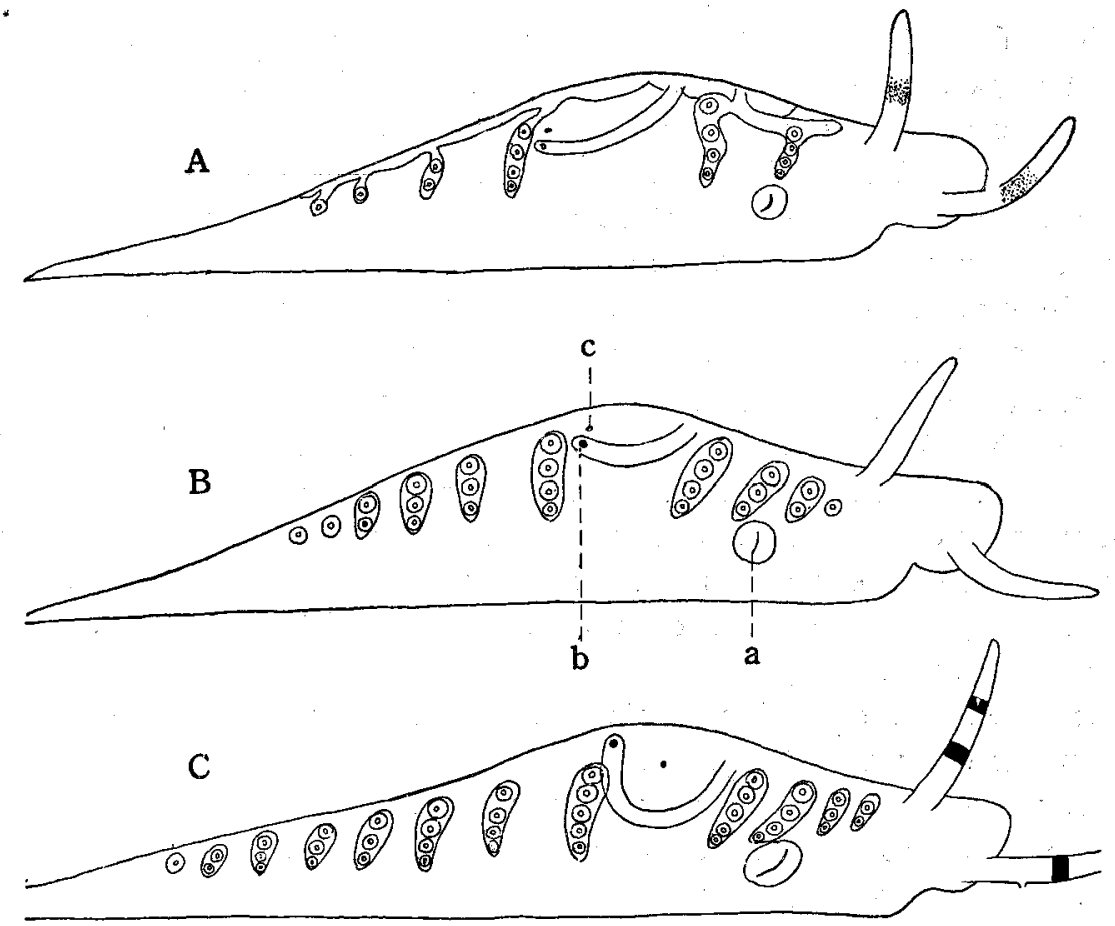

Fig. 1. Right side views of the three new species of Catriona.

A. C. pupillae (Mukaishima, Inland Sea of Seto) ; B. C. signifera (Tannowa, Osaka Bay);

C. C. purpureoanulata (Mukaishima). a. genital orifice, b. anus, c. nephroproct.

row on the right side, the anus in front of the 4th row on the same side, the nephroproct closely preanal. Foot-corners rounded. General body-colour translucent white, inclined to yellowish above, sprinkled with opaque white dots on head, back and tail. Upper half of cephalic tentacles and rhinophores opaque white. Branchial papillae opaque white towards the tip, their surface often streaked with longitudinal opaque white lines. Liver diverticulum within the papillae, dark green. The ovoid marking on the back is dark brown to black. Masticatory 
edge of the jaw-plates with a row of about 14 denticles. Radula formula $14 \times$ 0.1.0. Median cusp of the tooth as large as the lateral (5-6) denticles.

Loc.: Tannowa, Osaka Bay, on shore (Mar. 1951 and 1959, 12 sps., coll. by Mr. Hamatani) ; Mukaishima, Inland Sea of Seto, on Sargassum weeds in shallow water (Mar. 1960, 27 sps., coll. by Dr. INABA).

\section{Catriona purpureoanulata BABA, n. sp.}

Yubiwa-minoumiushi (n. n.)

(Pl. XV, Figs. 3, a, b-8; Text-fig. 1, C)

Animal 6-10 $\mathrm{mm}$ in length. Cephalic tentacles and rhinophores smooth. Branchial papillae long fusiform, disposed in 11-13 simple oblique rows on each side, 4-5 in the largest rows, the foremost 3-4 rows belonging to the right liver (and the left partner). Genital orifice below the middle of the right liver rows, the anus just in front of the 1st right row of the posterior liver, the nephroproct moderately preanal. Foot-corners rounded. Coloration distinctive in having a purple band down the tip of each of the branchial papillae. Two bands of purple occur also on cephalic tentacles and rhinophores each. General ground-colour translucent whitish, part of head and back covered with clusters of opaque white (or yellowish) dots. The two structures of the head also opaque white towards the tip. The cap of the branchial papillae opaque white, each papilla having a dark brown liver diverticulum. Foot-margin sometimes with a fine line of purple. A row of 15-17 denticles on the masticatory edge of the jaw-plates. Radula formula $22 \times 0.1 .0$. The median cusp of the tooth is as large as the lateral (usually 5) denticles.

Loc.: Seto, Kii, shallow water (June 1951, 1 sp.); Tannowa, Osaka Bay, shallow water (July 1957, 1 sp., coll. by Mr. HAMAtanI).

Additional localities of this species are: Hayama, Sagami Bay; Mukaishima, Inland Sea of Seto; Awashima, Niigata Pref.; Mera, Fukui Pref.; Tsuruga Bay; not rare. The actual specimens in these stations have been collected by His Majesty's Biological Laboratory, Dr. InABA, Mr. ABE and his co-workers.

\section{REFERENCES}

BABA, K. 1933. Supplementary note on the Nudibranchia collected in the vicinity of the Amakusa Marine Biological Laboratory. Annot. Zool. Japon., vol. 14, no: 2.

1937. Opisthobranchia of Japan (II). Journ. Dept. Agric. Kyushu Imp. Univ., vol. 5, no. 7 .

1949. Opisthobranchia of Sagami Bay. Iwanami Shoten, Tokyo.

1955. Opisthobranchia of Sagami Bay, Supplement. Iwanami Shoten, Tokyo.

Bergh, R. 1904. Nudibranchiata. SEMPER Reisen im Archipel der Philippinen. Wiss. Res., Bd. 9, Teil 6, Lief. 1. 
ELIOT, C. 1913. Japanese nudibranchs. Journ. Coll. Sci. Imp. Univ. Tokyo, vol 35, art. 1.

MACNAE, W. 1954. On some eolidacean nudibranchiate molluscs from South Africa. Ann. Natal Mus., vol. 13, pt. 1.

MARCus, E. 1958. On western Atlantic opisthobranchiate gastropods. Amer. Mus. Novitates, no. 1906.

MarcuS, E. \& E. 1959. Opisthobranchia aus dem Roten Meer und von den Malediven. Abh. math.-naturw. Klasse, No. 12.

ODHNer, N. 1939. Opisthobranchiate Mollusca from the western and northern coasts of Norway. Kgl. Norske Vidensk. Selskab. Skr., no. 1.

\section{Postscript}

Cotasiella formicaria (BABA, 1959)=Stiliger (Stiliger) formicarius BABA, 1959. This revised identification has been suggested to me by Dr. C. J. Risso Dominguez in Argentine, marking the similarity of formicarius to Costasiella Pruvot-Fol, 1951 (type: $C$. virescens from the Mediterranean) in the tentacular foot-corners and especially in the peculiar situation of the eyes lying close together. The genus Costasiella may be excluded from the Oxynoidae. References: BABA, K. 1959. The family Stiligeridae from Japan (Opisthobranchia-Sacoglossa). Publ. Seto Mar. Biol. Lab., vol. 7, no. 3, p. 329. Pruvot-Fol, A. 1951. Étude des nudibranches de la Méditerranée. Arch. Zool. Exp. et Gén., tom. 88, fasc. 1, p. 73. 


\section{EXPLANATION OF PLATES XIV-XV}

\section{Plate XIV}

Fig. 1a. Catriona pupillae (Tannowa, Osaka Bay, Mar. 13, 1951, length $5 \mathrm{~mm}$ ).

Fig. 1b. The same. A branchial papilla.

Fig. 2. The same. Jaw-edge $(\times 580)$.

Fig. 3. The same. A radula tooth $(\times 580)$.

Fig. 4. Catriona pupillae (Mukaishima, Inland Sea of Seto, Mar. 12, 1960, length $4 \mathrm{~mm}$ ). Diagrammatic representation of the internal anatomy. a. pharynx, b. oesophagus, c. stomach, d. genital orifice, e. right liver, f. rectum, g. nephroproct, h. anus, i. testes, j. ovaries, k. posterior liver, i. left liver, $\mathrm{m}$. special oral gland, $\mathrm{n}$. salivary gland.

Fig. 5. The same. Diagrammatic representation of the genitalia. a. penis, b. penis sac, c. penis stylet, d. genital orifice, e. vas deferens (glandular part), f. spermatheca, g. oviduct, h. albumen gland, i. hermaphrodite duct, j. mucous gland, k. ampulla, 1. penis gland.

Fig. 6a. Catriona signifera (Tannowa, Osaka Bay, Mar. 13, 1951, length $8 \mathrm{~mm}$ ).

Fig. 6b. The same. Two branchial papillae.

Fig. 7. The same. Jaw-edge $(\times 580)$.

Fig. 8. The same. A radula tooth $(\times 580)$.

Fig. 9. Catriona signifera (Mukaishima, Inland Sea of Seto, Mar. 15, 1960, length $7 \mathrm{~mm}$ ).

\section{Plate XV}

Fig. 1. Catriona signifera (Tannowa, Osaka Bay, Mar. 13, 1951, length $8 \mathrm{~mm}$ ). Diagrammatic representation of the internal anatomy. a. genital orifice, b. nephroproct, c. anus.

Fig. 2. The same. Diagrammatic representation of the genitalia. a. penis.

b. penis stylet, c. spermatheca, d. albumen gland, e. ampulla, f. mucous gland, g. penis gland.

Fig. 3a. Catriona purpureoanulata (Seto, Kii, June 22, 1951, length $6 \mathrm{~mm}$ ).

Fig. 3b. The same. A branchial papilla.

Fig. 4. The same. Jaw-edge $(\times 580)$.

Fig. 5. The same. A radula tooth $(\times 580)$.

Fig. 6. Catriona purpureoanulata (Mukaishima, Inland Sea of Seto (Apr. 2 , 1961, length $2 \mathrm{~mm}$ ). Diagrammatic representation of the internal anatomy. a. genital orifice, b. nephroproct, c. anus, d. kidney.

Fig. 7. The same. Part of the special oral gland $(\times 60)$.

Fig. 8. The same. Diagrammatic representation of the immature genitalia. a. penis stylet, b. spermatheca, c. accessory female gland, d. ampulla, e. penis gland. 
Publ. Seto Mar. Biol. Lab., IX, 2 (1961)

PlATE XIV

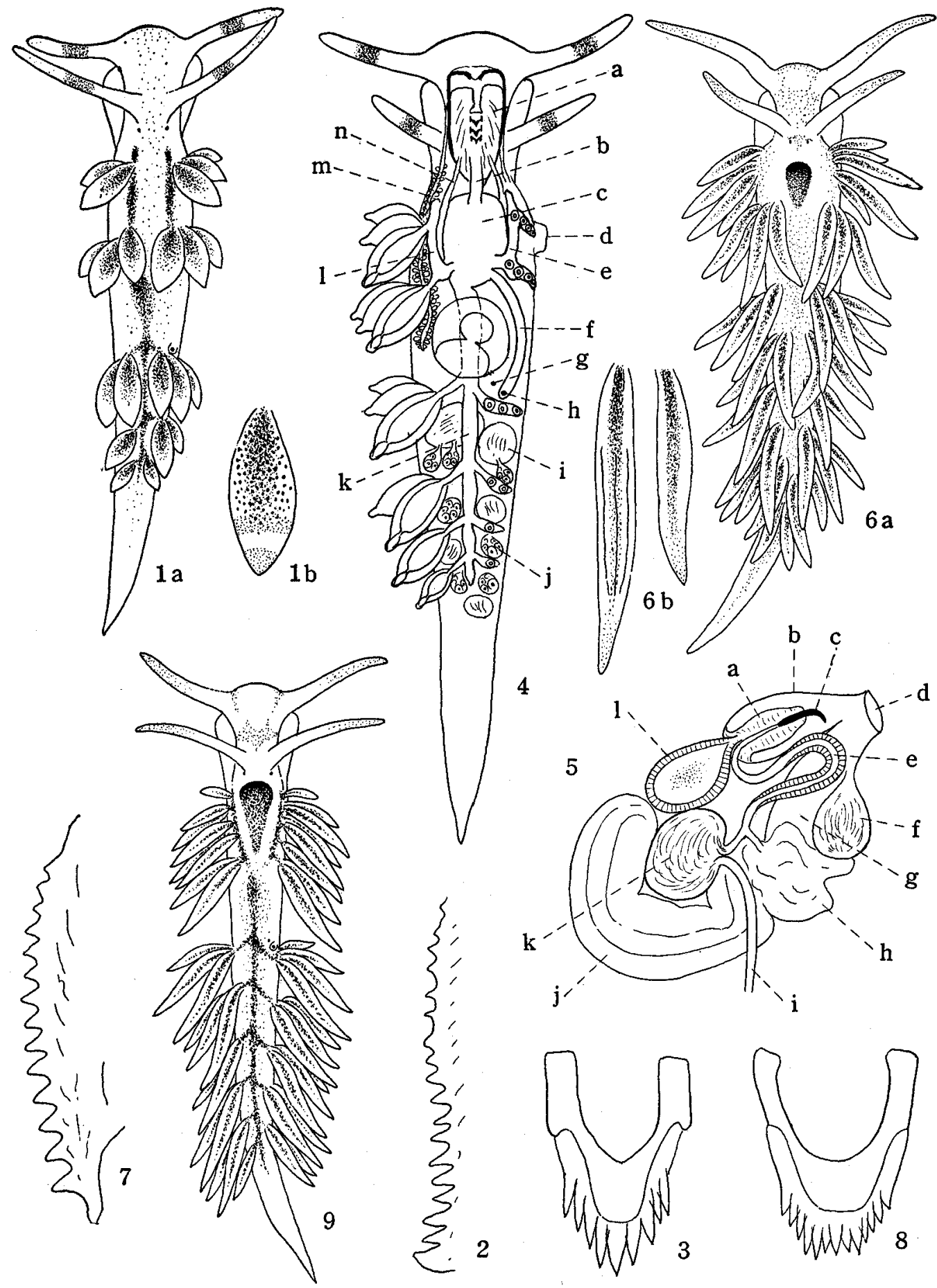

K, Baba; Three New Species of the Genus Catriona from Japan, 
Publ. Seto Mar. Biol. Lab., IX, 2 (1961)

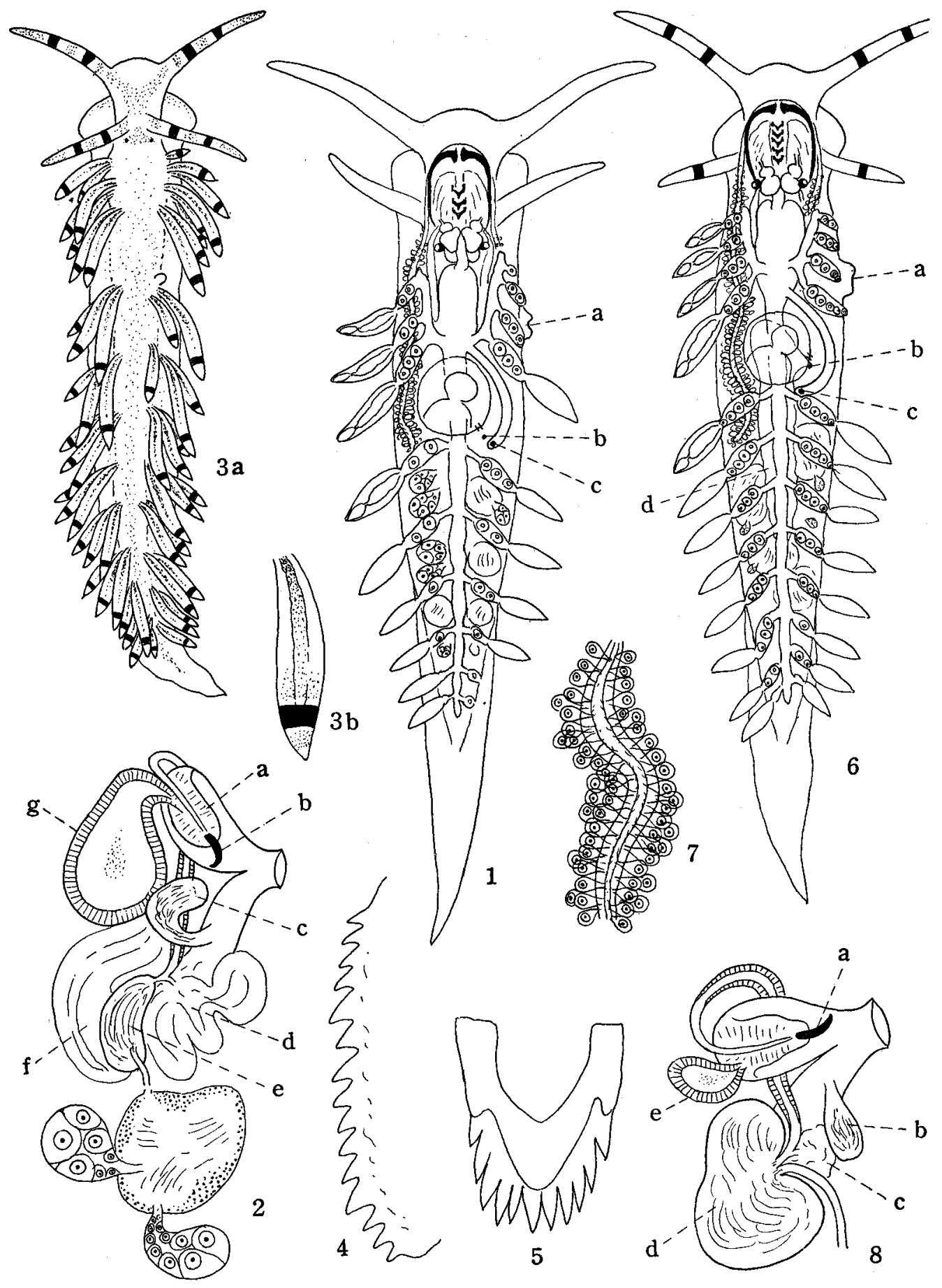

K, Baba; Three New Species of the Genus Catriona from Japan, 